CEPAL REVIEW 88 APRIL 2006

\title{
Celso Furtado's contributions to structuralism and their relevance today
}

\author{
Ricardo Bielschowsky
}

$\mathrm{T}$

his article examines Celso Furtado's three main analytical contributions to structuralism: (i) the historical-structural method, which incorporates the histories of Brazil and other Latin American countries in structuralist formulations; (ii) the belief that underdevelopment in the Latin American periphery has tended to persist over long periods owing to the difficulty of overcoming underemployment and to inadequate diversification of production; and (iii) the idea that the pattern of investments in the periphery is predetermined by the composition of demand, which mirrors and tends to preserve income and wealth concentration. Events in Latin America in the past twenty-five years show that Furtado's analysis has lost none of its relevance.

Ricardo Bielschowsky

Economic Affairs Officer ECLAC Office in Brasilia 


\section{Introduction}

This brief study outlines Celso Furtado's main contributions to structuralism, that is, to the theory of peripheral development developed by Raul Prebisch and ECLAC, and discusses why Furtado's important analytical contributions to Latin American and Brazilian debate on growth and development has had such a strong intellectual and ideological impact, especially in Brazil. A look at the main trends in Latin America and Brazil between 1980 and 2005 in the light of Furtado's contributions, which were written almost half a century ago, reveals how overwhelmingly upto-date those contributions still are. This is so for unfortunate reasons, however. The levels of growth, employment and income distribution in the region in the past 25 years have confirmed Furtado's scepticism concerning the prospects for development in the absence of well-designed and properly implemented national development projects.

\section{II}

\section{Prebisch and economic development under structural conditions of the periphery}

As a prelude to examining Furtado's contributions, it is necessary to turn briefly to Prebisch and his theory of peripheral conditions of development with respect to Latin America. ${ }^{1}$ This is because Furtado was a follower of Prebisch -the founder of Latin American structuralism- and because Prebisch's theory is rarely adequately addressed in the literature on economic development, most references being limited to the thesis on the worsening terms of trade. As Octavio Rodriguez correctly argued in his book on ECLAC thinking, ${ }^{2}$ Prebisch's theory constitutes an analytical corpus geared to the study of underdevelopment in Latin America.

According to this theory, constraints on growth stem from Latin America's specific position on the periphery of the developed world. Prebisch used the term "peripheral" economies in order to contrast them

This study was presented at the special session on "Celso Furtado and Latin America and the Caribbean. Trends and prospects", organized by ECLAC at the Tenth Meeting of the Latin American and Caribbean Economic Association, held in Paris in October 2005. The author wishes to thank Carlos Mussi and Carlos Aguiar de Medeiros for their useful comments on the text, and Franklin Serrano for the valuable discussion prior to its writing. The opinions expressed here are the sole responsibility of the author.

${ }^{1}$ Prebisch (1949) and ECLAC (1950 and 1951).

${ }^{2}$ See Rodriguez (1981). with the "central" economies. The main argument is that the differences between the two are associated with poor growth conditions in the periphery, which impose constraints on the industrialization process and technological progress and require growth strategies coordinated by the State, since, under those conditions, market forces are not sufficient, in themselves, to sustain viable growth.

Table 1 recapitulates the main elements of the Prebisch formulation on underdevelopment in Latin America and related problems, which was adopted by Furtado and other structuralist intellectuals.

It was on the basis of such a set of structural problems of the periphery that Prebisch and ECLAC built their analysis of growth, peripheral development and centre-periphery relations as well as their fundamental thesis: the worsening terms of trade, non-convergence between per capita income in the centre and the periphery, structural imbalance in the balance of payments, external vulnerability, saving and foreign-exchange gaps, and dynamic of the import substitution process.

In such a highly problematic environment, planning and State action were considered fundamental for sustaining industrialization and technical progress and for avoiding the perverse trends that are inherent in these conditions. For Prebisch, the main perverse trend was the structural imbalance in the balance of 


\begin{tabular}{ll}
\hline Features of Latin American economies & Implications for industrialization and growth \\
\hline Low productive diversity & $\begin{array}{l}\text { Need for simultaneous investment in many sectors -a very } \\
\text { demanding process in terms of savings, investment and foreign } \\
\text { exchange }\end{array}$
\end{tabular}

Specialization in agriculture and mining

Duality (or high degree of technological heterogeneity) -coexistence of high-productivity sectors with vast numbers of occupations that employ labour at near- subsistence levels

Lack of appropriate institutions and business capacity
Limited capacity to generate foreign exchange due to low international demand for exports, the worsening terms of trade, and the strong demand for foreign currency generated by high incomeelasticity of imports

Low average productivity and limited surplus, as a proportion of income

Low propensity to save and invest and insufficient capital accumulation and technological progress (part of the surplus is wasted through excessive consumption and unproductive investments) payments; in the view of some of his followers, such as Noyola Vásquez (1957) and Sunkel (1958), there was also a structural trend towards inflation. Furtado feared both ills, but his main analytical contribution had to do with the tendency to maintain underemployment and poor income distribution.

\section{III}

\section{Furtado's contributions to structuralism}

Furtado made three major contributions to the structuralist framework. First of all, Furtado endowed structuralism with a long-term historical perspective (1959 to 1970) and showed that, throughout centuries of alternating cycles of growth and contraction (in Brazil, the sugar-cane, mining and coffee cycles), each period has generated social and economic dualities (or heterogeneities), as well as a low level of diversification of production. Furtado's book The Economic Formation of Brazil $^{3}$ was a clear-and very successfulattempt to point out the historical elements in the formation of Brazil that justify the use of structuralism and of its economic policy conclusions (Bielschowsky, 1995). His objective was to demonstrate that the Brazilian economy had the characteristics of low diversity and duality described by Prebisch and that problems faced by the industrialization process in the 1950s were due to the historical and structural

${ }^{3}$ See Furtado (1959). constraints on growth resulting therefrom, hence the need for State coordination to overcome them.

Secondly, in the book "Desenvolvimento $e$ Subdesenvolvimento na América Latina" (1961), ${ }^{4}$ Furtado launched the debate on the difficulty of modern urban sectors to absorb the massive workforce streaming from countryside to city. He may have been the first to suggest that underemployment might become a long-term problem in Latin America and that the duality analysed by Lewis (1954) might persist. He was also one of the first to contend that the increase in productivity in modern sectors can coexist over a long period with low wages, thereby maintaining the poor secular distribution of income in Latin America. Furtado warned that, even if growth were sustained, it would be difficult to absorb the huge workforce available in Latin American societies; indeed, even if growth is sustained over a long period, the problems of

\footnotetext{
${ }^{4}$ See Furtado (1961).
} 
unemployment and underemployment, technological heterogeneity, income concentration and social injustice can persist.

Studies on Brazilian economic thinking ${ }^{5}$ do not find any prior arguments to Furtado's with this content, leading to the conclusion that it was Furtado, himself, who initiated the Latin American debate on the relationship between development, wage-setting and income concentration in conditions of rural and urban underemployment.

In his 1961 publication, which is a compilation of essays written in the second half of the 1950s, Furtado probably anticipated some of the basic ideas of the dependency theories debated throughout the 1960s. In his view, the Latin American growth model is one of the legacies of the developed economies' predominance over the rest of the world, which meant that, during industrialization of the periphery, modern foreign firms and their local competitors tend to share a production system with archaic structures. This leads peripheral systems to a new form of "dual" economy, based to a large extent on inappropriate production methods for processing local resources and incapable of overcoming the underdevelopment that characterizes a considerable part of the production system.

Furtado's third major contribution to structuralism appeared some years later, ${ }^{6}$ when he deepened his analysis of the relationship between growth and income distribution. He argued that the sectoral composition of investment and technological options were predetermined by income and wealth concentration, giving the modern fraction of the Latin American production structure a capital density similar to that of the developed countries. The technology used can help to maintain full employment and high wages in the latter, but is insufficient in Latin America to absorb the abundant labour supply and raise wages systematically. This model of investment implies maintaining unemployment, low wage levels and income concentration, which in a vicious circle, reinforces an inappropriate investment mix. Here again, he contrasted the periphery to the centre as a way of showing that, unlike what occurs in the countries of the centre, growth patterns in those of the periphery tend to preserve the abundance of labour and prevent improvements in productivity from being reflected in workers' income.

Two flaws in Furtado's analysis should be pointed out here. First, in the book he published in 1966, he stated that the Latin American growth and industrialization model showed diminishing returns, which resulted in a tendency to stagnation. Later, he had to abandon this idea, based on conclusive evidence of significant growth in the region. Second, he did not consider the possibility that birth control and a rapid growth in the existing distributive model would deplete the labour surplus. Nevertheless, none of the above can obscure the fact that Furtado -together with Maria da Conceiçao Tavares and Aníbal Pinto- ${ }^{7}$ launched the Brazilian and Latin American debate on growth and income distribution models.

In sum, Prebisch and Furtado's analytical scheme is a historical and structural analysis of the persistent productive heterogeneity and insufficient diversification of the production structure and is an analysis of the consequences of these two characteristics for growth, employment and income distribution, which should be taken as central references for formulating and implementing reform and development agendas.

\section{IV}

\section{Furtado's analytical contributions}

\section{and current economic trends in Latin America}

Statistical data on the socio-economic development of most Latin American countries in the past 25 years reveal a poor performance both in absolute terms and in comparison with the 30 previous years of State-led

\footnotetext{
${ }^{5}$ See, for instance, Bielschowsky, 1995 and 2000.

${ }^{6}$ See Furtado (1966, 1968, 1972 and 2000).
}

expansion: very low growth in GDP and productivity, much lower rates of investment, higher rates of unemployment and underemployment and income concentration rates that have not fallen despite the increase in social spending.

${ }^{7}$ See Tavares (1964) and Pinto (1965). 
None of this came as any surprise to Celso Furtado, who was always sceptical about the generation of growth and employment and income redistribution in Latin America in the absence of State-led growth strategies. Since the early 1980 s, he maintained on different occasions that this situation was the result of inappropriate reforms, lack of new developmentalist strategies and debt policy errors, capital volatility and globalization.

Furtado was joined in this criticism by a good number of other heterodox economists who followed the same line of thinking, believing that if Latin American economies continued to follow the course set by the liberalizing reforms, they would remain trapped in a process of weak investment, low employment and sluggish growth, with wages also at low levels, poverty and income concentration. It would be beyond the scope of this essay to review the interpretations of the currents of neoliberal and heterodox thinking in Latin America; suffice it to say that Prebisch and Furtado's analytical contribution have been enriching and of great value for analysing current trends.

This point is not immediately demonstrable since Prebisch died in the 1980s, while Furtado, who addressed the issue of trends only in brief articles, did not make any systematic analysis of the pattern of Latin American economic growth in the past 25 years. To overcome this limitation, a list of statements has been drawn up that could well have been made by either of these thinkers based on the theories that they formulated.

It should be noted that such statements, which are inspired by Prebisch and Furtado, are not based on any belief that it is possible to return to the policies of the 1950s, 1960s or 1970s. Certainly, it will mean bringing alternatives to neoliberal strategies in line with the new context: the economies are open to trade in goods and services, and growth-oriented macroeconomic policies are limited by the existence of uncontrolled financial markets and by the destabilizing influence of volatile capital flows and, in many countries, by large internal and external debts. In addition, national States are now more limited in terms of the resources at their disposal and their ability to put into practice development agendas. Nevertheless, none of this detracts from the validity of Prebisch and Furtado's analytical scheme for analysing Latin American trends and prospects and formulating new growth strategies.

As far as the economic trends of the past 25 years are concerned, the following statements could perfectly well have been formulated by Prebisch and Furtado: (i) In Latin America, the last 25 years have been a period of relative stagnation. There have been many changes, some of them positive -the end of high inflation and fiscal disequilibria and the increase in productivity in many sectors- but, on the whole, the result has been highly unfavourable, both economically and socially. This period marks the downturn of the long-term industrializationbased growth cycle, and it replicates some of the main characteristics of the downswings in past business cycles (such as agricultural and mining cycles): inadequate diversification, heterogeneity and underemployment, low returns to labour and income concentration;

(ii) With few exceptions, in most countries, economic policy and the reforms carried out contributed to a relative de-industrialization, with the loss of production chains and of inter- and intra-sectoral complementarities in the manufacturing sector. The region has witnessed a reversal of the previous trend towards productive diversification, together with a premature de-industrialization process (UNCTAD, 2003), which occurred before the region reached the stage of building up technologyintensive sectors and providing an environment conducive to a proper innovation system. This has weakened the structural foundation for growth.

(iii) It has been a period of mounting heterogeneity across sectors, subsectors and firms. Large national and foreign corporations are operating state-of-theart plants, but modernity has been poorly and unevenly diffused through the economic system. The increase in productive heterogeneity is particularly striking in the labour market, where the share of total employment represented by lowproductivity sectors is on the rise.

(iv) Underemployment and unemployment explain why, in spite of the increase in social expenditure, income distribution has remained rigid; any rise in productivity that occurs has been used primarily to boost profits and, in some cases, to cover the wages of highly-skilled labour, with very little trickling down to the masses of unskilled workers. The above statements may be summed up as follows: the poor performance of the Latin American economies over the past 25 years was due largely to the implementation of the wrong reforms and policies -both with respect to resource allocation and to macroeconomic and financial matters- and to the lack of national development strategies. This performance resulted in inadequate diversification of production, 
structural heterogeneity, unemployment and underemployment, low wages, poverty and income concentration, and in the persistence of foreign exchange gaps, external vulnerability and per capita income disparity compared with the developed economies.

The work of Prebisch and Furtado can also serve as inspiration in analysing the future outlook for the region. For instance, it may be said that, as in other past downswings in the region throughout the 500 years of its economic history (when long periods of time passed before growth was reestablished), so far no new engine of growth has emerged. The key questions are: Is this going to be a protracted period of stagnation in which duality, heterogeneity, external balance-of-payments constraints and "divergence" will continue? What are the potential driving forces for investment, technological progress and productivity growth in Latin American economies today? Can some new model of growth be envisaged? What are the connections between possible strategies for achieving economic prosperity in the future and employment and income distribution?

\section{Furtado, structuralism and neostructuralism}

If it is granted that this list of statements is relevant to an understanding of trends in the past 25 years, then the relevance of the Prebisch-Furtado approach must also be conceded.

Many of the best heterodox interpretations of current trends in Latin America provide sound analyses of monetary and financial issues in line with ECLAC neostructuralism ${ }^{8}$ and related schools of thought. These texts were a necessary advance with respect to the initial structuralist interpretations, especially in the present era of macroeconomic uncertainty, capital volatility and financial constraints. ${ }^{9}$

At the mesoeconomic and microeconomic levels, the analytical capacity of the neostructuralists of today does justice to the founders of this school of thought. Current publications clearly show the need to encourage infrastructure and technology-intensive investments, to build national innovation systems and promote education, and to foster sectoral complementarities, clusters and small and medium-sized enterprises.

Nevertheless, if the work of present day neostructuralists is compared with that of their

\footnotetext{
${ }^{8}$ This expression was coined after the ECLAC economists assimilated the irreversibility of the liberalizing reforms, whose flaws they criticized, and made recommendations for correcting the course. The pioneering document with respect to the neostructural phase -Changing Production Patterns with Social Equity (ECLAC, 1990)was coordinated by Fernando Fajnzylber, who transmitted to ECLAC the thinking that had been developed in the previous years (see Fajnzylber, 1989).

${ }^{9}$ See, for example, ECLAC (1995 and 2002); Ffrench Davis (1999), and Ocampo, Bajraj and Martin (2001).
}

precursors, the former provide an insufficient analysis of the determining factors of investment and growth models.

Capital accumulation was a structuralist and Furtadian obsession which, unfortunately, has now fallen into disuse. The neo-structuralist analysis of the issue is sound insofar as it relates the scarcity of investments to macroeconomic uncertainties, including capital volatility and exchange-rate and interest-rate instability and the contraction and fluctuation in levels of activity. But little has been said about the relationship between the propensity to invest and reforms (trade liberalization and privatization) or about the propensity to invest in general.

In one of the few studies on this issue, Moguillansky and Bielschowsky (2001) argue that opening up the economy causes domestic firms in tradable-goods sectors to experience a decline in profitability and a rise in levels of risk and uncertainty, which amounts to lower incentives for investment. Also, before privatization, when State-owned firms made investments, they were less concerned about profitability, as well as being less averse to risk and uncertainty. This suggests that privatizations reduce the propensity to invest in the economy, although they can perhaps increase the microeconomic efficiency of investments. There is, therefore, good reason to believe that the current low propensity to invest may have a great deal to do with the reforms and that the new context requires some sort of public-private coordination in order to boost investment.

Lastly, neo-structuralism owes much to original structuralism in terms of alternative growth models to 
the neoliberal model which take into account the peculiar conditions of each Latin American country. Much would be gained from a return to the practice of formulating national development projects following Furtado's line of thinking, namely, that of growth patterns or models, which others -such as Anibal Pinto, Conceiçao Tavares and Jose Serra, and Pedro Sainz and Alfredo Calcagno- ${ }^{10}$ sometimes called "models" or "styles" of growth.

From a historical and structuralist perspective, a pattern of growth is a historically-determined, countryspecific combination of a number of structural elements which are responsible for the dynamic of growth, investment, productivity, employment and wages. The most important of these elements are: (i) the principal investment agents (the State, local and foreign capital); (ii) the financial equation for investment (retained profits versus domestic and foreign finance); (iii) the composition of production and of foreign trade, together with the associated technological choices; (iv) the direction of growth -inward, outward, or both; (v) trends in employment and underemployment; and (vi) trends in income and wealth distribution.

These factors, taken in conjunction with the macroeconomic regime and financial relationships with the rest of the world and institutions existing in each country, provide a good road map for an investigation into what is going on today in each Latin America country. On this basis, it may be possible to come up with a map of similarities and differences in the behaviour of individual countries that may help to design development projects for each nation and construct a broad and diversified strategic agenda for the region as a whole.

\section{VI}

\section{Summary and conclusion}

This brief article has presented Celso Furtado's three main analytical contributions to structuralism.

The first, which forms the basis of the historicalstructural method, was the incorporation of Brazilian and Latin American history into structuralist formulations. The second was the belief that underdevelopment in the Latin American periphery tends to persist over long periods owing to two deeply entrenched conditions: underemployment and inadequate diversification of production. According to Furtado, underdevelopment is not simply a phase of transition towards development, but a more permanent phenomenon, which cannot be overcome without a tenacious and long-term political commitment.

The third contribution is based on the idea that investment patterns in the periphery are predetermined by the composition of demand, which reflects income and wealth concentration. In Latin America, supply structures, which are inappropriate for absorbing the abundant labour force, are being reproduced, keeping wages low and tending to reinforce the unequal pattern of income distribution.

\footnotetext{
${ }^{10}$ See Pinto (1976); Tavares and Serra (1972), and Sainz and Calcagno (1992).
}

In the light of developments in Latin America in the past 25 years, Furtado's analysis, unfortunately remains fully relevant. The two central elements of underdevelopment -namely, the insufficient diversity of the production base and the structural duality or heterogeneity- have not been overcome, and as a result, wages have remained low, and income concentration and poverty levels, high.

An agenda inspired by Celso Furtado for surveying current trends and future prospects for Latin America would undoubtedly provide a comprehensive and necessary analysis and would confirm the validity and relevance of his contributions. ${ }^{11}$

(Original: Portuguese)

\footnotetext{
${ }^{11}$ In the case of Brazil, Furtado's approach, far from being a mere research agenda, was adopted as a national development project within the 2004-2007 Multi-year Plan (Brazil, 2003). Although this plan was signed by the President of the Republic and adopted by Congress, unfortunately, it does not seem to have been adopted, disseminated and properly implemented by the Government. Nevertheless, it sets out an encouraging long-term development strategy, whose conceptual basis is precisely Furtado's work of the 1960s and 1970s, in which he calls for the formation of a virtuous circle of investment, wages and consumer rights.
} 
Bibliography

Bielschowsky, R. (1995): Pensamento econômico brasileiro. O ciclo ideológico do desenvolvimentismo, Rio de Janeiro, Contraponto.

(2000) (org): Cinqüenta anos de pensamento na CEPAL: uma resenha, Rio de Janeiro, Record.

Brazil (2003): Plano plurianual 2004-2007, Brasilia, Ministry of Planning, Budget and Management.

ECLAC (Economic Commission for Latin America and the Caribbean) (1949): Economic survey of Latin America, 1949, E/CN.12/ 164/rev.1, Santiago, Chile.

(1951): Economic Survey of Latin America, 1950, E/CN.12/ 217/Rev.1, Santiago, Chile.

(1990): Changing production patterns with social equity: the prime task of Latin American and Caribbean development in the 1990s, Santiago, Chile, LC/G.1601-P, Santiago, Chile, March. United Nations publication, Sales No. E.90.II.G.6.

(1995): Latin America and the Caribbean: Policies to Improve Linkages with the Global Economy, LC/G.1800/ Rev.1-P, Santiago, Chile. United Nations publication, Sales No. E.95.II.G.6.

(2002): Globalization and Development, LC/G.2157 (SES.29/3), Santiago, Chile, April.

Fajnzylber, F. (1990): Industrialization in Latin America: from the "black box" to the "empty box": a comparison of contemporary industrialization patterns, Cuadernos de la CEPAL series, No. 60, LC/G.1534-P, Santiago, Chile. United Nations publication, Sales No. E.98.II.G.5.

Ffrench Davis, R. (1999): Macroeconomía, comercio y finanzas: para reformar las reformas en América Latina, Santiago, Chile, ECLAC/McGraw-Hill. Furtado, C. (1959): Formacão econômica do Brasil, Rio de Janeiro, Fundo de Cultura.

(1964): Development and Underdevelopment, Berkeley, California, University of California Press.

(1966): Subdesenvolvimento e estagnação da América

Latina, Rio de Janeiro, Civilização Brasileira.

(1968): Um projeto para o Brasil, Rio de Janeiro, Saga.

(1972): Análise do "modelo" brasileiro, Rio de Janeiro,

Fundo de Cultura.

(1979): Formação econômica da América Latina, Rio de Janeiro, Cia Editora Nacional.

(2000): Teoria e política do desenvolvimento econômico, Rio de Janeiro, Paz e Terra.

Lewis, W. (1954): Economic development with unlimited supplies of labour, Manchester School of Economic and Social Studies, vol. 22, Manchester, The Manchester School of Economic and Social Studies.

Moguillansky, G. and R. Bielschowsky (2001): Investment and Economic Reform in Latin America, LC/G.2128-P, Santiago, Chile, Economic Commission for Latin America and the Caribbean (ECLAC)/Fondo de Cultura Económica. United Nations publication, Sales No. E.01.II.G.21.

Noyola-Vásquez, J. (1957): Inflación y desarrollo económico en México y Chile, Panorama económico, No. 170, Santiago, Chile, July.

Ocampo, J.A, R. Bajraj and J. Martin (coords.) (2001): Una década de luces y sombras. América latina y el caribe en los años noventa, Santafé de Bogotá, ECLAC/Alfaomega.

Pinto, A. (1969): Concentration of Technical Progress and its Fruits in Latin American Development, Santiago, Chile, Editorial Universitaria.

(1970): Naturaleza e implicaciones de la 'heterogeneidad estructural' de la América Latina”, El trimestre económico, No. 145, January-March.

(1976): Notas sobre los estilos de desarrollo en América Latina, CEPAL Review, No. 1, Santiago, Chile.

Prebisch, R. (1950): The economic development of Latin America and its principal problems (E/CN.12/89/Rev.1), Lake Success, New York, United Nations. United Nations publication, Sales No. 50.II.G.2

Rodriguez, O. (1981): Teoria do subdesenvolvimento da CEPAL, Rio de Janeiro, Forense/ Universitária.

Sunkel, O. (1958): La inflación chilena, un enfoque heterodoxo, El trimestre económico, vol. 25(4), No. 100, Mexico City., Fondo de Cultura Económica, October-December.

Sainz, P. and A. Calcagno (1992): In search of another form of development, CEPAL Review, No. 48, LC/G.1748-P, Santiago, Chile, December.

Tavares, M.C. (1964): The growth and decline of import substitution in Brazil, Economic Bulletin for Latin America, vol. 9, No. 1, Santiago, Chile, Economic Commission for Latin America and the Caribbean, March.

(1979): Auge e declínio da substituição de importações, Da substituição de importações ao capitalismo financeiro, Rio de Janeiro, Zahar.

Tavares, M.C. and J. Serra (1972): Além da estagnação, Da substituição de importações ao capitalismo financeiro, Rio de Janeiro, Zahar.

UNCTAD (United Nations Conference on Trade and Development) (2003): World Investment Report, Geneva, United Nations. 